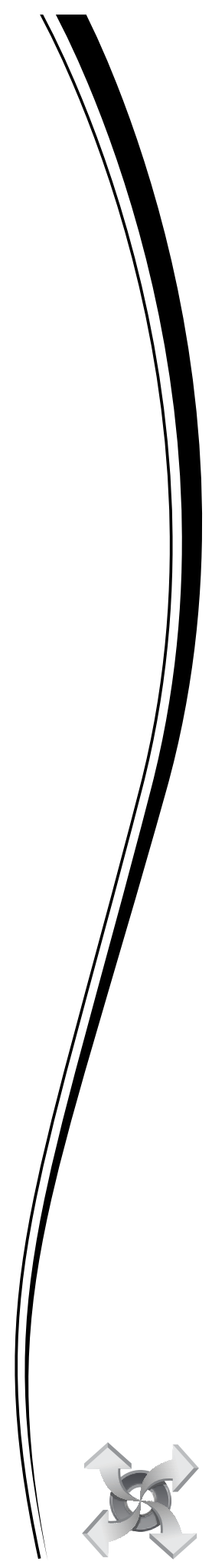

Jurnal Ekonomi, Manajemen dan Akuntansi Islam I M A NEN S I Volume 1

Nomor 1

Halaman 1-74

Malang, September 2013 ISSN 2339-1847

\title{
EKONOMI ISLAM ATAU IQTISHAD?
}

\author{
Anis Byarwati ${ }^{11}$ \\ Tjiptohadi Sawarjuwono ${ }^{2)}$ \\ 1)Universitas Yarsi, Menara Yarsi, Kav. 13, Lt 1, Jakarta. \\ ${ }^{2)}$ Universitas Airlangga, Surabaya \\ Email: anis.byarwati@yarsi.ac.id
}

\begin{abstract}
Abstrak. Ekonomi Islam atau Iqtishad? Telaah Kritis terhadap Penggunaan Istilah "Ekonomi Islam". Istilah Ekonomi Islam dan Iqtishadmengemuka ditahun 1970-an melalui literatur yang ditulis para ahli. Kajian ini bertujuan untuk menelaah secara kritis penggunaan istilah Ekonomi Islam. Proses penelaahan menggunakan pendekatan analisis wacana. Melaluistudi literatur, kajian ini mengupassejarah serta perkembangan istilah Ekonomi dan Iqtishad. Kemudian data yang ada diinterpretasikan. Kesimpulannya, kajian ini berhasil mengungkapadanya pergeseran filosofidan makna dari kata ekonomi, sehingga penggunaan istilah Ekonomi Islam menjadi tidak tepat lagi. Sedangkan istilah Iqtishadterbuktimemiliki filosofi dan makna yang lebih sesuai untuk digunakan.
\end{abstract}

Abstract. Islamic Economics or Iqtishad? Critical Analysis to the Use of "Islamic Economics". The term Islamic Economics and Iqtishad surfaced in the 1970s through various literatures. This analysis is aimed to criticize the use of the term Islamic Economics. Discourse analysis was utilised. Through iterature studies, this article explored the history and the development of the term Economics and Iqtishad. Data was then interpreted. The results indicate that there is a shift of philosophy and meaning of economics, hence the use of Islamic Economics is no longer appropriate. The use Iqtishad proves to have philosophy and meaning that are more appropriate to be used.

Kata Kunci: Istilah, Ekonomi Islam, Iqtishad,Analisis Wacana

Meskipun wacana mengenai Ekonomi Islam telah mengemuka sejak dekade 1970-an,akan tetapi harus diakui bahwa istilahEkonomi Islam masih merupakan "barang baru" dalam disiplin Ilmu Ekonomi. Istilah Ekonomi Islam juga masih diperdebatkan tentang ada atau tidaknya, apakah Islam memiliki suatu sistem ekonomi ataukah sebatas aturan-aturan normatif saja. (Hasanuzzaman 1991:21-22; Schacht 1974:104).

Tidak bisa dipungkiri bahwa istilah Ekonomi Islam melahirkan efek beragam. Untuk sebagian kalangan, kata 'Islam' memposisikan Ekonomi Islam pada tempat yang sangat eksklusif, hanya untuk kalangan muslim, sehingga menghilangkan nilai kefitrahannya se- bagai tatanan bagi semua manusia. Untuk lainnya, ekonomi Islam digambarkan sebagai ekonomi hasil racikan antara aliran Kapitalis dan Sosialis, sehingga ciri khas khusus yang dimiliki oleh Ekonomi Islam itu sendiri hilang.

Hingga saat ini, istilahEkonomi Islam masih multi interpretable, dengan begitu banyaknya ahli yang memberikan definisi dan pemaknaan. ${ }^{1}$ Kemudian terdapat

1 Misalnya, Dawam Rahardjo memilah istilah ekonomi Islam ke dalam tiga kemungkinan pemaknaan, pertama yang dimaksud ekonomi Islam adalah ilmu ekonomi yang berdasarkan nilai atau ajaran Islam. Kedua, yang dimaksud ekonomi Islam adalah sistem. Sistem menyangkut pengaturan yaitu pengaturan kegiatan ekonomi dalam 
pula istilahIqtishad ${ }^{2}$ yang diajukan oleh beberapa pemikir Muslim, diantaranya yang dianggap fonumenal adalah Muhammad Baqir Ash Shadr. ${ }^{3}$ Iqtishad, selama ini lebih sering dianggap dan digunakan sebagai terjemahan untuk istilah ekonomi.

Penulis tertarik untuk menyoroti lebih dalam tentang dua istilah ini, ekonomi Islam dan Iqtishad. Istilah pertama, Ekonomi Islam menggabungkan dua kata: Ekonomi dan Islam. Kata Islam setelah Ekonomi berfungsi sebagai identitas tanpa mempengaruhi makna atau definisi dari istilah ekonomi. Oleh sebab itu, dalam memahami istilah Ekonomi Islam, tidak akan bisa terlepas dari makna atau definisi dari istilah ekonomi.

Istilah ekonomi sendiri telah digunakan selama berabad-abad, dan telah menjadi bagian yang menyertai perjalanan kehidupan manusia. Kata "ekonomi" berasal dari penggabungan dua suku kata Yunani: oĩkos (oikos) yang berarti "keluarga, rumah tangga" dan vójos (nomos), yang berarti "peraturan, aturan, hukum," dan secara garis besar diartikan sebagai "aturan keluarga (rumah tangga)" atau "manajemen keluarga (rumah tangga)" (Deliarnov 2003:11). Secara ringkas, ekonomi adalah aturan-aturan untuk menyelenggarakan kebutuhan hidup manusia di dalam rumah tangga, baik dalam rumahtangga individu maupun dalam rumahtangga yang bersifat kolektif dalam suatu negara (Deliarnov, 2003: 11-17), atau secara populer, Ekonomi didefinisikan sebagai pengetahuan tentang peristiwa dan persoalan yang berkaitan dengan upaya manusia secara perseorangan (pribadi), kelompok (keluarga, suku bangsa, organisasi) dalam memenuhi kebutuhan yang tidak ter-

suatu masyarakat atau negara berdasarkan suatu cara atau metode tertentu. Sedangkan pilihan ketiga adalah ekonomi Islam dalam pengertian perekonomian umat Islam. (lihat Rahardjo, M. Dawam (1999), Islam dan Transformasi Sosial Ekonomi, Jakarta, LSAF 1999:3-4)

2 Konsep Iqtishad akhir-akhir ini menjadi obyek kajian yang serius di Barat terbukti dengan banyaknya literatur yang mulai bermunculan dalam artikel-artikel penelitian maupun buku yang mengangkatnya sebagai tema utama. (Lihat Olivier Roy, 1996,The Failure, alih bahasa Carol Volk, cet. 2, Harvard Universiry Press, hlm. 133.

3 Muhammad Baqir Ash-Shadradalah salah satu tokoh intelektual muslim kontemporer asal Iraq yang hadir dengan gagasan original tentang sistem Iqtishad yang digali dari landasan Islam yakni alQur'an dan al-Hadits. Ash-Shadr tidak sepakat bahwa Iqtishad merupakan sistem ekonomi yang sama batas yang dihadapkan pada sumber yang terbatas.

Di kalangan masyarakat, istilah ekonomi lebih sering dipahami sebagai segala sesuatu yang berhubungan dengan materi, kebendaan, dan kekayaan. Dalam realitas kehidupan masyarakat modern, ekonomi dijadikan sebagai salah satu indikator untuk menilai kesuksesan seorang individu. Dalam tatanan kehidupan bernegara, ekonomi bahkan menjadi indikator utama yang menentukan sebuah Negara digolongkan sebagai Negara Maju, Negara Berkembang atau Negara Terbelakang. Hal ini semakin menguatkan makna dari istilah ekonomi yang dikaitkan dengan materi, kebendaan, dan kekayaan tersebut.

Berbeda dengan istilah ekonomi yang telah mendunia, istilah Iqtishad belum populer di kalangan masyarakat dan masih sangat terbatas penggunaannya. Ibnu Manzur (tt) dalam Lisan al-Arab menulis kalimat Iqtisad berasal dari akar kata Qashadu/ Qashdu yang berarti lurus, sebagaimana disebutkan dalam firman Allah dalam QS Al-Nahl ayat 9 : Dan hak bagi Allah (menerangkan) jalan yang lurus, dan di antara jalan-jalan ada yang bengkok. dan Jikalau Dia menghendaki, tentulah Dia memimpin kamu semuanya (kepada jalan yang benar). Sedangkan Al-Zabidi (tt) dalam kitab TajalArus menyebut Iqtisad berasal dari kalimat Qashada/Qashdu yang berarti sederhana, yang berada di antara bakhil dan israf.

Dengan demikian Iqtishad berarti upaya untuk melakukan sesuatu atau mengatur sesuatu sesuai dengan ketentuan, adil, dan seimbang. Penggunaan kata Iqtishad juga mengandung arti lurus, mencari keuntungan tanpa menindas orang (golongan) lain, mengutamakan keadilan dan keseimbangan dalam masyarakat yang tingkat ekonominya berbeda-beda.

sebagaimana sistem ekonomi sebelumnya seperti Kapitalisme dan Sosialisme. Dedikasi Ash-Shadr terhadap pemikiran ekonomi Islam diwujudkan dalam magnum opusnya, Iqtishaduna, yang telah diterjemahkan kedalam beberapa bahasa sampai saat ini. Melalui Iqtishaduna, Ash-Shadr dengan sangat tajam melontarkan kritik terhadap pemikiran ekonomi konvensional. Karya Ash-Shadr ini dianggap sebagai karya pionir yang komprehensif dalam literatur Ekonomi Islam. (Lihat Byarwati. Penemuan Madzhab Ekonomi Islam: Studi Discourse Analysis Terhadap Pemikiran Muhammad Baqir Ash-Shadr Dalam Kitab Iqtishaduna, Disertasi Program Doktor Program Studi Ilmu Ekonomi Islam Universitas Airlangga Surabaya, Oktober 2012). 
Dari uraian di atas dapat disimpulkan bahwa antara istilah Ekonomi dan Iqtishad terdapat perbedaan.

Dalam tinjauan analisis wacana, ilmu pengetahuan secara inheren merupakan bagian dan dipengaruhi oleh struktur sosial dan diproduksi dalam interaksi sosial (Fairclough 1995a; Scott 1988). Pandangan ini melihat bahasa (tulisan, percakapan, bahasa tubuh) sebagai social practice yang kemudian disebutkan dengan istilah discourse (wacana). Joan Scott (1988) secara lebih luas mendefnisikan wacana atau discourse sebagai sesuatu yang bukan hanya sebatas bahasa (language) atau teks semata, tetapi struktur spesifik dari pernyataan-pernyataan, istilah-istilah, kategori-kategori dan kepercayaan-kepercayaan yang dikonstruksi secara historis, sosial dan institusional. Dengan mendeskripsikan wacana sebagai praktik sosial, ada implikasi-implikasi yang muncul, yakni dialektika hubungan antara kejadian diskursif tertentu dengan situasi serta institusi dan struktur sosial yang melingkupinya.

Karena itulah dalam tinjauan analisis wacana, sebuah istilah tidak muncul begitu saja. Sebuah istilah juga tidak hanya memuat pengertian, makna, atau definisi. Istilah memuat filosofi, ideologi, pikiran, maksud, dan memiliki tujuan tertentu dari sang produsen yang melahirkan atau yang memunculkannya. Filosofi dan ideologi inilah yang menjadi dasar dan menggerakkan suatu konsep, termasuk konsep ekonomi.

Ketika sebuah istilah dimunculkan dan mengemuka di tengah masyarakat, lalu diterima dengan pemahaman tertentu yang sesuai dengan keinginan sang produsen, maka istilah ini telah menjadi wacana publik (public discourse). Selanjutnya, istilah yang menjadi wacana publik akan menjadi sarana efektif untuk menggiring masyarakat ke arah tujuan yang diinginkan oleh si produsen. Dalam pandangan Van Dijk (1999, 2003), tujuan produksi wacana berkaitan dengan ideologi produsen wacana itu sendiri.

Dikaitkan dengan istilah Ekonomi dan Iqtishad, kedua istilah inipun tidak muncul begitu saja. Keduanya memiliki asal-usul dan sumber masing-masing. Istilah Ekonomi dilahirkan dari peradaban Yunani, dan selanjutnya berkembang secara pemikiran, teori, dan prakteknya di tengah-tengah masyarakat Barat, hingga mencapai masa kejayaannya di Barat. Disiplin ekonomi Barat pada dasarnya dikembangkan berdasarkan nilai dan ideologi hidup yang dianut masyarakat Barat. (Polli 2010, h. 7). Mengikuti pandangan Van Dijk $(1999,2003)$ bahwa tujuan produksi wacana berkaitan dengan ideologi produsen wacana itu sendiri, maka dapat dikatakan istilah ekonomi berkaitan dengan filosofi dan ideologi yang dianut masyarakat Barat.

Sedangkan Iqtishad lahir dari ajaran Islam, dan secara konsep dan prakteknya dipengaruhi oleh seperangkat nilai (set of values) yang dianut oleh masyarakat Islam sepanjang sejarahnya, sejak masa Rasulullah SAW, Khulafa' al-Rasyidun, dan kemudian diwariskan kepada Daulah 'Umayyah, Daulah Abbasiyah, dan seterusnya hingga sekarang selama lebih dari 14 abad. Mengikuti pandangan Van Dijk $(1999,2003)$ bahwa tujuan produksi wacana berkaitan dengan ideologi produsen wacana itu sendiri, maka dapat dikatakan istilah Iqtishad berkaitan dengan filosofi dan ideologi yang dianut masyarakat Islam.

Tulisan ini bermaksud mengkaji secara kritis tentang penggunaan istilah Ekonomi Islam dan Iqtishad. Pembahasan dilakukan melalui studi literatur. Bahan yang digunakan sebagai sumber data penelitian digali melalui dokumentasi, yaitu semua data yang tertulis yang dapat digunakan sebagai sumber informasi. Untuk membahas masalah yang dikaji, penulis menggunakan pandangan Van Dijk $(1999,2003)$ tentang analisis wacana sebagai pisau analisis.

Sejauh yang teramati, belum banyak peneliti yang mengupas secara khusus dan detail tentang istilah Ekonomi Islam dan Iqtishad, dan apakah keduanya bermakna sama. Para Ahli lebih banyak langsung membahas pengertian dan konsep-konsep dalam Ekonomi Islam tanpa mempermasalahkan apakah istilah Ekonomi Islam itu sendiri sudah tepat digunakan. Akan halnya Ash Shadr yang mengemukakan istilah Iqtishad sebagaimana disebutkan di atas, ia tak menjelaskan dalam bukunya mengapa ia memilih istilah Iqtishad dan menolak istilah Ekonomi Islam. ${ }^{4}$

Begitu pula, dua istilah ini belum pernah diteliti dengan menggunakan pendekatan analisis wacana. Dengan demikian tulisan ini bertujuan untuk melengkapi dan mempertajam kajian serupa yang telah ada

4 Pemikiran Ash Shadr secara khusus tentang hal ini telah diteliti oleh Penulis dalam bab IV Disertasi Penulis (lihat catatan kaki no.2). 
sebelumnya. Dengan harapan hasil kajian ini dapat memperkaya bahan bacaan mengenai studi Ekonomi dan studi Analisis Wacana.

\section{PEMBAHASAN}

Menapaki jejak ke belakang, istilah ekonomi yang diambil dari kata Oekonomia ${ }^{5}$ pertama kali digunakan oleh Xenophone pada tahun ke 5 sebelum Masehi (Deliarnov: 2003, h. 11). Oeconomia didefinisikan Aristoteles sebagai "the art of household management, the administrations of one's patrimony, the careful husbanding of resources". (Polli: 2010, h. 6). Maknanya, spirit ethics dan kekeluargaan menjadi jiwa dan asas (fondasi) dalam pengelolaan aktivitas ekonomi, sosial dan politik masyarakat. Di awal tumbuhnya di masa Yunani pra-klasik (469$322 \mathrm{SM}$ ), ditemukan bahwa seluruh kegiatan masyarakat dalam bidang ekonomi berasaskan kekeluargaan. (Deliarnov 2003:11-17).

Keluarga adalah miniatur dari masyarakat dan bangsa. Mengelola masyarakat dan bangsa seperti mengelola keluarga dalam lingkup yang besar. Dalam kehidupan berkeluarga, setiap anggota keluarga saling membantu, saling menyayangi dan saling melindungi. Maka, dengan spirit 'oikonomia' (manajemen keluarga) ini, dimasa itu orang-orang Yunani melakukan berbagai kegiatan ekonomi seperti produksi, konsumsi, dan terlibat dalam kegiatan ekonomi dalam berbagai bentuk, termasuk pertukaran perdagangan jarak jauh, dan mengembangkan sistem moneter yang menggunakan mata uang, dengan berlandaskan semangat kekeluargaan.

Spirit oikonomia dengan titik tekan padaethics dan manajemen keluarga (rumah tangga) menjadi jiwa dan asas (fondasi) dalam pengelolaan aktivitas ekonomi, sosial dan politik masyarakat, sebagai makna sesungguhnya dari kata ekonomi ini dikuatkan oleh tulisan dari Aristoteles, murid dari Plato. Dalam bukunya, 'Politics', Aristoteles menguraikan tentang tahapan membangun negara. Di awali dengan membangun rumah tangga atau keluarga (oikos), sejumlah keluarga akan membentuk desa, sejumlah desa

5 Meskipun kata Yunani kuno oikonomia adalah akar dari kata Inggris modern "economy," kata kedua tidak bermakna sama. Kata "economy" saat ini mengacu pada lingkup yang berbeda yang melibatkan interaksi manusia dalam produksi, distribusi, dan konsumsi barang dan jasa, sebagaimana terdapat dalam buku-buku teks ekonomi modern. akan membentuk negara (kota; polis). Menurut Aristoteles, mengatur rumah tangga, desa dan negara yang membedakan hanyalah ruang lingkupnya. Rumah tangga, desa, dan negara terbentuk secara alamiah untuk memenuhi tujuan eksistensinya masing-masing. Di masa itu, seluruh kegiatan ekonomi, sosial, dan politik merupakan bentuk implementasi dari sistem nilai Yunani yang menekankan kesejahteraan masyarakat di atas kepentingan individu. (Polli 2010:6-8).

Makna oikonomia ini masih konsisten digunakan di masa Skolastik (abad XIII-XIV) di Eropa dengan tokohnya Thomas Aquinas dan Albertus Magnus yang dikenal sebagai tokoh gereja. Pada perkembangan selanjutnya, makna istilah ekonomi mulai mengalami pergeseran di masa Merkantilis (abad XVII-XVIII) sebagai akibat munculnya Revolusi Industri, dimana studi ekonomi mulai dipisahkan dari pengaruh agama. Hal ini berarti, studi ekonomi menganut ideologi sekularisme yang memisahkan hal-hal yang bersifat spiritual dan material (atau agama dan dunia) secara dikotomis. Segala hal yang terkait dengan dunia adalah urusan manusia itu sendiri sedangkan agama hanya mengurusi hubungan antara manusia dengan Tuhannya. Implikasi dari ini adalah menempatkan manusia sebagai sebagai pusat dari segala hal kehidupan (antrophosentris) yaitu manusialah yang berhak menentukan kehidupannya sendiri.

Abad ini dianggap sebagai benih cikal bakal tumbuhnya Kapitalisme, diantara tokohnya adalah Jean Boudin, Thomas Munn, Jean Baptist Colbert, David Hume. Di masa ini, ekonomi berideologi sekuler, dan makna ekonomi telah bergeser dari maknanya yang semula adalah pengelolaan aktivitas ekonomi, sosial, dan politik dengan kekeluargaan sebagai ruh (spirit) utamanya, bergeser menjadi pengelolaan ekonomi, sosial, dan politik dengan spirit utama individualisme.

Selanjutnya, ideologi dan makna baru dari istilah ekonomi ini kemudian menguat di masa Fisiokrat (abad XVIII) dengan tokoh utamanya Francis Quesnay, dan akhirnya mendapatkan pengakuan sebagai sebuah teori dan sistem ekonomi tersendiri di masa klasik (abad XVIII) melalui tokohnya Adam Smith. Tulisan Adam Smith dalam "An Inquiry into the Nature and Causes of the Wealth of Nations" pada tahun 1776, merupakan kontribusi untuk melahirkan ekonomi sebagai satu disiplin ilmu yang didasarkan pada masyarakat yang memiliki ideologi sekuler- 
dan invidualisme, yang berakar pada filosofi materialisme.(Deliarnov 2003:11-17), (Polli 2010:6-8). Adam Smith menyatakan bahwa tindakan individu yang mementingkan kepentingan diri sendiri pada akhirnya akan membawa kebaikan masyarakat seluruhnya karena tangan tak tampak (invisible hand) yang bekerja melalui proses kompetisi dalam mekanisme pasar. (Samuelson dan Nordhaus 2001:30-31 dan 216)

Ekonomi menempatkan manusia sebagai homo economicus atau economic man adalah manusia yang materialis hedonis, sehingga ia selalu dianggap memiliki serakah atau rakus terhadap materi. Dalam perspektif materialisme hedonisme murni, segala kegiatan manusia dilatarbelakangi dan diorientasikan kepada segala sesuatu yang bersifat material. Manusia dianggap merasa bahagia jika segala kebutuhan materialnya terpenuhi secara melimpah. Pengertian kesejahteraan yang materialistis seperti ini seringkali menafikan atau paling tidak meminimalkan keterkaitannya dengan unsur-unsur spiritual ruhaniah. Dalam ekonomi, materi adalah sangat penting bahkan dianggap sebagai penggerak utama perekonomian. Dari sinilah sebenarnya, istilah kapitalisme berasal, yaitu paham yang menjadikan kapital (modal / material) sebagai isme. (Chapra 2001:3)

Sejak saat itu, hampir semua negara di dunia menggunakan istilah ekonomi dengan filosofi,ideologi dan makna yang telah bergeser dan menjadikannya sebagai sistem ekonomi negara. Hal ini berarti bahwa sekularisme dan individualisme yang berakar pada filosofi materialisme telah menjadi ruh dari kegiatan ekonomi hampir di seluruh negara di dunia ${ }^{6}$. Ekonomi yang semula dekat dengan nilai-nilai agama, dipisahkan dari agama. Filosofikekeluargaan yang dilandasi cinta dan kasih sayang, telah bergeser menjadi individualisme yang mengutamakan kepuasan materi sebagai tujuannya.

6 Negara Indonesia sendiri, meskipun secara konsep tetap konsisten berpegang pada makna asal ekonomi, sebagaimana tercantum dalam Pasal 33 UUD 1945 ayat 1 yang menyebutkan bahwa "perekonomian disusun sebagai usaha bersama berdasar atas azas kekeluargaan", namun secara realita tidak demikian. (Lihat Swasono, Sri-Edi, Pasar-Bebas yang Imajiner: Distorsi Politik dan Pertentangan Kepentingan Internasional, Mimeo, Kantor Menko Ekuin, 21 Maret 1997;Lihat juga, Swasono, Sri-Edi, 2008, Ekspose Ekonomika, Mewaspadai Globalisme dan Pasar Bebas, Yogyakarta: Pusat Studi Ekonomi Pancasila Universitas Gajah Mada.
Dari penjelasandi atas dapat diketahui bahwa pergeseran filosofi,ideologi dan makna dari istilah ekonomi ini tidak terjadi dengan sendirinya, melainkan dimunculkan secara perlahan dalam waktu yang relatif lama (lebih dari 22 abad). Para tokohnya telah berhasil menjadikan filosofi, ideologi dan makna baru istilah ekonomi sebagai wacana publik yang mampu menggeser tata kehidupan masyarakat, dan membawa dampak yang sangat serius terhadap kehidupan manusia selanjutnya, dimana Sekularisme dan Individualisme yang terpusat pada kepuasan materi telah menjadi ideologidan makna baru bagi ekonomi dan menjiwai seluruh pembahasannya. Dalam perjalanannya, secara konsep dan praktek, ideologimaterialisme, sekularisme dan individualisme telahmenjadi ruh dari ekonomi, yang ikut berkontribusi dalam membentuk individu dan masyarakat dunia menjadi individu dan masyarakat yang sekuler, materialis, dan individualis.

Selama ini, Iqtishad dianggap sebagai terjemahan bahasa Arab untuk istilah ekonomi. Benarkah demikian? Sebagai sebuah istilah, kata Iqtishad tidak ditemukan pada literatur keislaman klasik. Ia merupakan kosa kata baru. Hasil penelusuran literatur terhadap kata ini menunjukkan bahwa istilahIqtishad dimunculkan pertama kali oleh Al-Ghazali (1058-1111) dalam kitabnya yang terkenal Ihya 'Ulum Ad-Din. Dalam kitabnya ini, Al-Ghazali menyatakan mempelajari ilmu Iqtishad adalah wajib bagi setiap muslim yang bekerja (kullumuslimmuktasab) sebagaimana kewajiban menuntut ilmu yang lain. Sedangkan tujuan mempelajarinya tidak lain adalah untuk menghindari kesulitan dalam bermu'amalah dan hal-hal yang dapat menjerumuskan kepada larangan-larangan agama, dan agar tidakterjadi kerusakan dalam kehidupan ekonomi secara luas. ${ }^{7}$ Kemudian tahun 1902, istilah Iqtishad muncul dalam buku yang membahas beberapa persoalan ekonomi, berjudul Ilm Al-Iqtishadkarya Muhammad Iqbal (1876-1938), seorang tokoh pembaharu Islam dari India. (Dimyati 2007:3)

IstilahIqtishadmerupakantashrif (bentuk perubahan) dari kata qashada (دصق) yang terdapat dalam Al-Qur'an dan al

7 Lihat Al-Gazali, Ihya 'UlumAd-Din, vol. 2, hlm. 66. Lihat juga Dimyati, 2007, Teori Keuangan Islam,Rekonstruksi Metodologis Terhadap Konsep Keuangan al-Ghazali, Yogyakarta: UII Press. 
Hadits. Iqtishadsecara literal berarti 'seimbang' (equilibrium, balanced) dan'tengahtengah' (in between). Dalam kata al-qasdu juga terkandung makna 'al-tawassuth' (pertengahan, moderat), dan 'al-i'tidal' (sikap adil). ${ }^{8}$ Makna-makna ini sangat dekat dengan salah satu Hadits Rasulullah saw, yang diriwayatkan oleh Iman Ahmad sebagai berikut: "Tidak akan miskin orang yang bersikap 'iqtashada' (pertengahan, moderat, adil) dalam pengeluaran/pembelanjaan".

Sedangkan dalam Al-Qur'an, kata (دصق) dan tasrifnya disebutkan sebanyak enam kali didalam al-Quran, sebagai berikut:

Dalam surah Al-Nahl ayat 9, kata qashdu al-sabil (ثَنُْ السَّبيل) diartikan sebagai jalan yang lurus, terjemah ayatnya sebagai berikut:

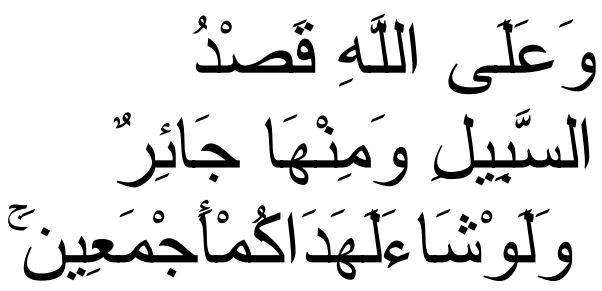

"Dan hak bagi Allah (menerangkan) jalan yang lurus, dan di antara jalanjalan ada yang bengkok. dan Jikalau Dia menghendaki, tentulah Dia memimpin kamu semuanya (kepada jalan yang benar)."

Dalam surat Al-Luqman ayat 32, kata muqtashidun (دصِنَقَقُْ juga diartikan jalan yang lurus.

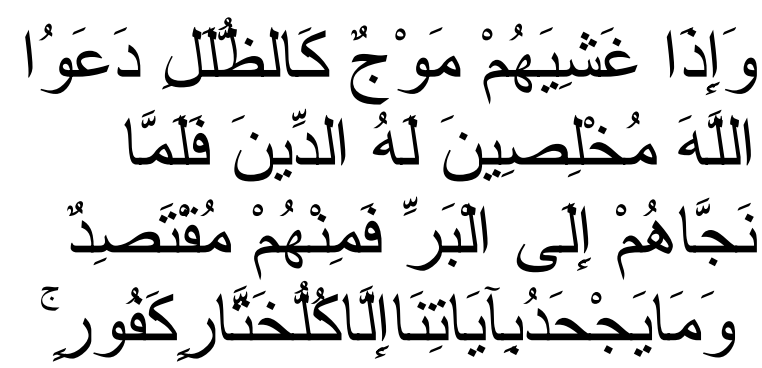

Dan apabila mereka dilamun ombak yang besar seperti gunung, mereka menyeru Allah dengan memurnikan ketaatan kepadaNya Maka tatkala Allah menyelamatkan mereka sampai di daratan, lalu sebagian mereka tetap menempuh jalan yang lurus, dan tidak ada yang mengingkari ayat-ayat Kami selain orang-orang yang tidak setia lagi ingkar.

8 Muhammad JawwadMugniyah, at-Tafsir alKasysyaf(Beirut: Dar al-Fikr, 1968), Vol. 3, hlm. 90. BandingkandenganAr-Ragib al-Isfahani, MufradatAlfaz al-Quran (ttp: MaktabahMurtadawiyah, $1362 \mathrm{H})$, hlm. 404.
Dalam surat Al-Fatir ayat 32, kata muqtashidun, (دصنَقٌُْ), diartikan pertengahan.

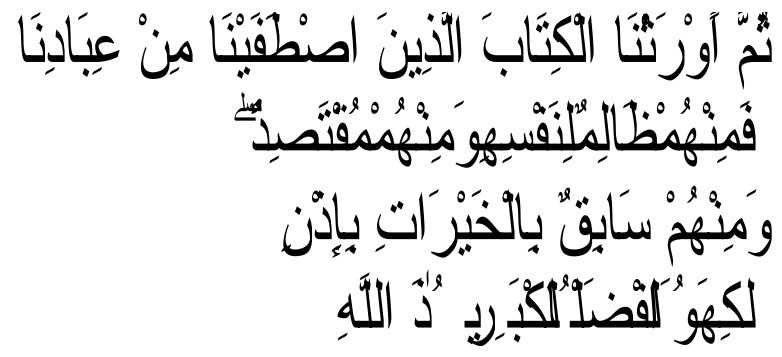

Kemudian kitab itu Kami wariskan kepada orang-orang yang Kami pilih di antara hamba-hamba Kami, lalu di antara mereka ada yang Menganiaya diri mereka sendiri dan di antara mereka ada yang pertengahan dan diantara mereka ada (pula) yang lebih dahulu berbuat kebaikan ${ }^{9}$ dengan izin Allah. Yang demikian itu adalah karunia yang Amat besar.

Dalam surat Al-Maidah ayat 66, kata

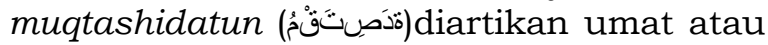
golongan pertengahan.

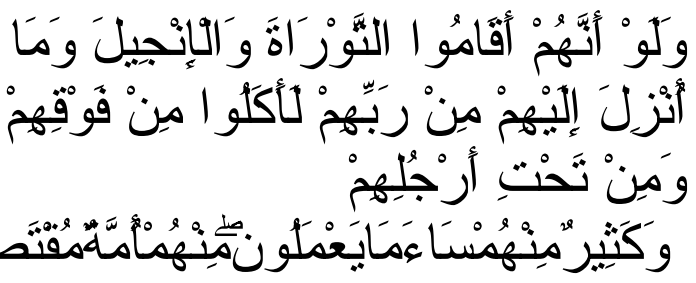

Dan Sekiranya mereka sungguh-sungguh menjalankan (hukum) Taurat dan Injil dan (Al Quran) yang diturunkan kepada mereka dari Tuhannya, niscaya mereka akan mendapat makanan dari atas dan dari bawah kaki mereka ${ }^{10}$. Diantara mereka ada golongan yang pertengahan ${ }^{11}$ dan Alangkah buruknya apa yang dikerjakan oleh kebanyakan mereka.

9 Yang dimaksud dengan orang yang menganiaya dirinya sendiri ialah orang yang lebih banyak kesalahannya daripada kebaikannya, dan pertengahan ialah orang-orang yang kebaikannya berbanding dengan kesalahannya, sedang yang dimaksud dengan orang-orang yang lebih dahulu dalam berbuat kebaikan ialah orang-orang yang kebaikannya Amat banyak dan Amat jarang berbuat kesalahan (Departemen Agama RI)

10 Maksudnya: Allah akan melimpahkan rahmat-Nya dari langit dengan menurunkan hujan dan menimbulkan rahmat-Nya dari bumi dengan menumbuhkan tumbuh-tumbuhan yang buahnya melimpah ruah. (Departemen Agama RI)

11 Maksudnya: orang yang Berlaku jujur dan Lurus dan tidak menyimpang dari kebenaran (Departemen Agama RI) 
Dalam surat Al-Luqman ayat 19, kata waaqshid, (دصنقاوَ), berarti sederhana.

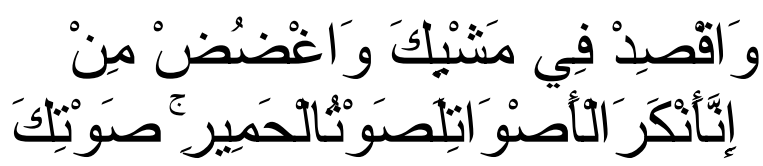

Dan sederhanalah kamu dalam berja$l^{l a n^{12}}$ dan lunakkanlah suaramu. Sesungguhnya seburuk-buruk suara ialah suara keledai.

Dalam ayat 42 surat At-Taubah, kata qaashidan, (ادَصناقَ), diartikan (perjalanan) yang sederhana dan dekat.

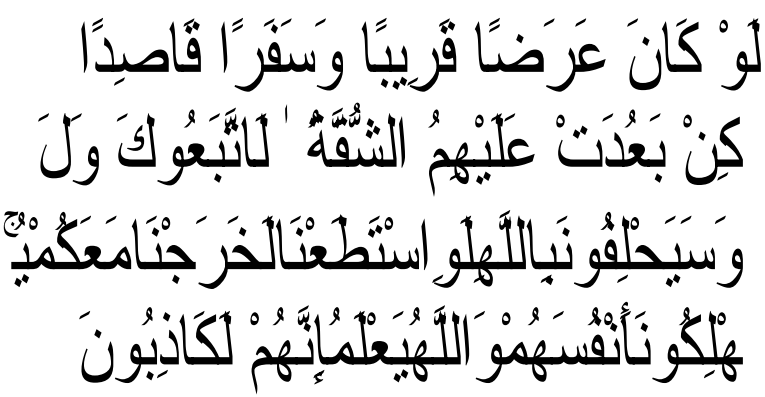

Kalau yang kamu serukan kepada mereka itu Keuntungan yang mudah diperoleh dan perjalanan yang tidak seberapa jauh, pastilah mereka mengikutimu, tetapi tempat yang dituju itu Amat jauh terasa oleh mereka. mereka akan bersumpah dengan (nama) Allah: "Jikalau Kami sanggup tentulah Kami berangkat bersama-samamu." mereka membinasakan diri mereka sendiri dan Allah mengetahui bahwa Sesungguhnya mereka benarbenar orang-orang yang berdusta.

Sedangkan Al-Misri (2005:11) berpendapat bahwa istilah Iqtishad pada hakekatnya bermakna al-Qashdu yang berarti al-tawasuth (pertengahan) dan al-I'tidal (adil/berkeadilan). Definisi ini mengacu pada ayat al-Qur'an yang terdapat dalam QS. Lukman: 19 dan QS. al-Maidah : 66, kedua ayat ini telah dituliskan di atas.

Dari penjelasan yang diuraikan secara rinci di atas dapat disimpulkan bahwa makna al-Iqtishadadalah melakukan sesuatu atau mengatur sesuatu sesuai dengan ketentuan, adil, dan seimbang. Penggunaan kata Iqtishad juga mengandung arti berkegiatan lurus, mencari keuntungan tanpa menindas orang (golongan) lain, mengutamakan keadilan dan keseimbangan dalam masyarakat yang tingkat ekonominya berbeda-beda. Iqti-

12 Maksudnya: ketika kamu berjalan, janganlah terlampau cepat dan jangan pula terlalu lambat (Departemen Agama RI) shad tidak bisa dipisahkan dari ajaran Islam dan secara konsep maupun prakteknya harus sesuai dan tidak boleh bertentangan dengan sumber nilai Islam Al-Qur'an dan As-Sunnah.

Iqtishadmelihat persoalan pemenuhan kebutuhan manusia tidak hanya berkaitan dengan faktor produksi, konsumsi, dan distribusi, berupa pengelolaan sumber daya yang ada untuk kepentingan bernilai materi. Akan tetapi, lebih dari itu, Iqtishadmelihat persoalan tersebut sangat terkait dengan persoalan moral, ketidakadilan, dan ketauhidan. Sehingga dalam kajiannya, Iqtishadmenempatkan individu (manusia) sebagai objek kajian, tidak hanyadengan memposisikannya sebagai mahluk sosial, tetapi juga sekaligus sebagai mahluk yang mempunyai potensi religius. Oleh sebab itu, Iqtishadmenggunakanfilosofi nilai-nilai Islam sebagai dasar pijakannya.

Hal inilah yang secara mendasar membedakan Iqtishaddengan konsep ekonomi yang menempatkan kepentingan individu sebagai landasannya. Konsep Iqtishadtidak hanya berkaitan dengan proses pemenuhan kebutuhan manusia semata,tetapi juga sekaligusterkait dengan tujuan dilakukannya proses itu, yaitu untuk kepentingan yang lebih utama berupa kesejahteraan ukhrawi.

Makna Iqtishad yang menjadikan keadilan dan sikap pertengahan sebagai ruhnya inilah yang diimplementasikan secara nyata dalam kehidupan masyarakat Islam di sepanjang sejarahnya, semenjak zaman Rasulullah SAW, kemudian diteruskan oleh para Khulafa Rasyidin dan masa-masa setelahnya. Sejarah menjadi bukti, Iqtishad yang menjadi sistem negara telah menjadikan Pemerintahan Islam tangguh dan mampu mencapai kejayaannya selama berabad-abad. Jika pun setelah masa jayanya, pemerintahan Islam mengalami keterpurukan, maka hal itu lebih disebabkan oleh faktor politik, bukan karena faktor kelemahan konsepiqtishad. ${ }^{13}$

Bertitik tolak dari pembahasan di atas, dapat disimpulkan bahwa istilahIqtishad tidak tepat diposisikan sebagai terjemahan dari istilah ekonomi. Masing-masing istilah itu memiliki akar filosofi dan ideologinya

13 Lihat Perwataatmadja, Karnaen A dan Anis Byarwati, 2008, Jejak Rekam Ekonomi Islam: Refleksi Peristiwa Ekonomi Dan Pemikiran Para Ahli Sepanjang Sejarah Kekhalifahan, Jakarta: Cicero Publishing. 
Tabel 1. Perbedaan antara IstilahEkonomi dan Iqtishad

\begin{tabular}{|c|c|c|c|}
\hline NO & POIN PERBEDAAN & EKONOMI & IQTISHAD \\
\hline & Pengertian & $\begin{array}{l}\text { upaya manusia secara } \\
\text { perseorangan (pribadi), } \\
\text { kelompok (keluarga, suku } \\
\text { bangsa, organisasi) dalam } \\
\text { memenuhi kebutuhan yang } \\
\text { tidak terbatas yang } \\
\text { dihadapkan pada sumber } \\
\text { yang terbatas }\end{array}$ & $\begin{array}{l}\text { Upaya manusia untuk } \\
\text { melakukan/mengatur } \\
\text { sesuatu sesuai dengan } \\
\text { ketentuan, adil, dan } \\
\text { seimbang. Lurus, mencari } \\
\text { keuntungan tanpa } \\
\text { menindas orang (golongan) } \\
\text { lain, mengutamakan } \\
\text { keadilan dan keseimbangan } \\
\text { dalam masyarakat }\end{array}$ \\
\hline 2. & Sumber Utama & $\begin{array}{l}\text { - Pemikiran para tokohnya } \\
\text { - Pembentukan teori dan } \\
\text { konsepnya bertumpu pada } \\
\text { pemikiran para tokohnya. }\end{array}$ & $\begin{array}{l}\text { Al-Qur'an, As-Sunnah, } \\
\text { Nilai-nilai Islam } \\
\text { - Pembentukan teori dan } \\
\text { konsepnya harus } \\
\text { merujuk serta tidak } \\
\text { boleh bertentangan pada } \\
\text { sumber utama Islam. }\end{array}$ \\
\hline 3. & Ideologi & $\begin{array}{l}\text { - Sekularisme } \\
\text { \&Individualisme }\end{array}$ & - Islam \\
\hline 4. & Filosofi & $\begin{array}{l}\text { - Materialisme, terpusat pada } \\
\text { kepuasan materi. Materi } \\
\text { dianggap sebagai penggerak } \\
\text { utama perekonomian. } \\
\text { - menempatkan manusia } \\
\text { sebagai sebagai pusat dari } \\
\text { segala hal kehidupan yaitu } \\
\text { manusialah yang berhak } \\
\text { menentukan kehidupannya } \\
\text { sendiri. }\end{array}$ & $\begin{array}{l}\text { - At-tawasuth } \\
\text { (pertengahan), Seimbang } \\
\text { pada pemenuhan materi } \\
\text { dan spiritual } \\
\text { - } \text { didasarkan pada } \\
\text { keyakinan bahwa semua } \\
\text { termasuk diri manusia } \\
\text { pada dasarnya adalah } \\
\text { milik Allah, dan } \\
\text { kepadaNya (kepada } \\
\text { aturanNya) dikembalikan } \\
\text { segala urusan }\end{array}$ \\
\hline 5 . & Posisi & $\begin{array}{l}\text { - Bukan merupakan sistem } \\
\text { nilai yang mengikat. }\end{array}$ & $\begin{array}{l}\text { merupakan bagian dari } \\
\text { sistem nilai yang } \\
\text { mengikat seorang } \\
\text { muslim untuk diterapkan } \\
\text { dalam kehidupan } \\
\text { - menjadi bagian dari } \\
\text { kewajiban agama. }\end{array}$ \\
\hline & Gagasan Utama & $\begin{array}{l}\text { - Kepentingan Individu di atas } \\
\text { segalanya } \\
\text { - Persaingan antar individu } \\
\text { untuk mencapai kepuasan } \\
\text { maksimal }\end{array}$ & $\begin{array}{l}\text { - Al-adalah (keadilan) } \\
\text { - menempatkan individu } \\
\text { (manusia) sebagai mahluk } \\
\text { sosial sekaligus sebagai } \\
\text { mahluk religius. }\end{array}$ \\
\hline
\end{tabular}

masing-masing, sebagai dasar pijakan yang melahirkan dan menggerakkan konsep dan teorinya.

Secara ringkas, perbedaan antara istilah ekonomi dan Iqtishad dapat dilihat sebagaimana disajikan dalam tabel berikut:

Perbedaan istilah ekonomi dan Iqtishad sebagaimana disajikan dalam tabel di atas membawa implikasi terhadap penggunaan istilah Ekonomi Islam. Merujuk pada tabel di atas dan mempertimbangkan berbagai perbedaan, utamanya perbedaanfilosofi dan ideologidi antara dua istilah tersebut, masih relevan-kah penggunaan istilah Ekonomi Islam?

Iqtishad memiliki gagasan, konsepsi, filosofi pemikiran, norma, budaya, kultur, keyakinan, dan ideologinya yang berakar 
kuat pada Islam. Iqtishad tidak bisa dipisahkan, ia terintegrasi dalam kerangka sistem Islam yang utuh dan sempurna. Karena itu, Iqtishad adalah konsep yang genuine, ia tidak bisa diidentikkan dengan Ekonomi Islam, yang berdasar namanya mencampuradukkan antara Islam dengan ekonomi yang berideologi sekuler.

Iqtishad tidak bisa disamakan dengan ekonomi. Begitu pula, tidak bisa memasukkan Iqtishad sebagai bagian/cabang dari ekonomi, hanya karena ditemukan beberapa kemiripan didalamnya, baik secara teori maupun praktek.

Dalam pandangan penulis, istilahEkonomi Islam yang menggabungkan antara ekonomi dengan Islam,tidak tepat dan tidak lagi relevan untuk digunakan. Di samping itu, penggunaan istilah Ekonomi Islam telah menyebabkan istilahIqtishaddipahami secara tidak tepat. Diantara pemahaman yang berkembang dewasa ini terhadap Iqtishaddapat penulis sebutkan sebagai berikut; pertama: dianggap sama saja dengan ekonomi konvensional, yang membedakan hanya tujuannya ${ }^{14}$; kedua: merupakan cabang dari ilmu ekonomi dalam perspektif Islam ${ }^{15}$; ketiga: sebagai upaya memahami problem ekonomi yang diilhami nilai-nilai Islam ${ }^{16}$; keempat: merupakan perpaduan antara ilmu ekonomi konvensional dengan fiqh muamalah ${ }^{17}$.

\section{SIMPULAN}

Kajian ini menghasilkan beberapa kesimpulan sebagai berikut. Pertama, kajian ini

14 Rahardjo berkesimpulan bahwa ilmu Ekonomi Islam sama saja dengan ilmu ekonomi umumnya, yaitu menyelidiki perilaku manusia dalam kegiatan produksi, distribusi dan konsumsi yang menyangkut pilihan terhadap sumberdaya yang sifatnya langka dan alokasi sumberdaya tersebut guna memenuhi kebutuhan manusia. Dalam Islam, yang membedakan hanyalah tujuan kegiatannya, yang menjadikan targetnya untuk mencapai tujuan yang lebih tinggi, yaitu kebahagian hidup di dunia maupun di akhirat, dengan melakukan ibadah kepada Allah. Ilmu Ekonomi Islam memperhatikan dan menerapkan syariah dalam perilaku ekonomi dan dalam pembentukan sistem ekonomi. Lihat Dawam. 1999. Islam dan Transformasi Sosial-Ekonomi.

15 Pandangan ini diantaranya disampaikan oleh Chapra yang mengungkapkan bahwa Ekonomi Islam adalah "Economics with an Islamic Perspective." Yang dimaksudkan Chapra dengan 'Economics' adalah disiplin Ekonomi Konvensional. Adapun 'Islamic Perspective' yakni pandangan hidup Islam, karena ia juga menghubungkan terminologi 'Perspective' dengan terminologi-terminologi lain seperti 'vision', dan 'worldview' Jadi secara singkatnya, menurut Chapra, Ekonomi Islam adalah Ekonomi Konvensional yang sejalan dengan pandangan hid- menguatkan teori bahwa ilmu pengetahuan secara inheren merupakan bagian dan dipengaruhi oleh struktur sosial dan diproduksi dalam interaksi sosial (Fairclough 1995a; Scott 1988). Pandangan ini melihat bahasa (tulisan, percakapan, bahasa tubuh) sebagai social practice yang kemudian disebutkan dengan istilah discourse

up Islam. Lihat, M. Umer Chapra, The Future of Economics - An Islamic Perspective (Leicester : The Islamic Foundation, 2000), hal 2. Pendapat ini juga disampaikan oleh Khurshid Ahmad, menurutnya Ekonomi Islam adalah "a sistematic effort to try to understand the economic problems and man's behaviors in relation to that problem from an Islamic perspective" (Upaya sistematis untuk mencoba memahami permasalahan ekonomi dan perilaku manusia dalam kaitannya dengan masalah itu dari perspektif Islam). Lihat Khursid Ahmad (1992:9) dalam M. Umer Chapra, What is Islamic Economics, (Jeddah: IRTI - IDB).

16 Manan (1992) berpendapat bahwa ilmu Ekonomi Islam dapat dikatakan sebagai ilmu pengetahuan sosial yang mempelajari masalah-masalah ekonomi masyarakat yang diilhami nilai-nilai Islam. Ia mengatakan bahwa Ekonomi Islam merupakan bagian dari suatu tata kehidupan lengkap, berdasarkan empat bagian nyata dari pengetahuan, yaitu: alQuran, as-Sunnah, Ijma dan Qiyas. (Lihat M. Abdul Mannan, Islamic Economics: Theory and Practice., Delhi.Sh. M. Ashraf, 1970. Lihat juga M.A Mannan, The Making of an Islamic Economic Society, Cairo, 1984:18).

17 Daulay berpandangan bahwa Ilmu Ekonomi Islam pada dasarnya merupakan perpaduan antara dua jenis ilmu yaitu ilmu ekonomi dan fiqh mu'amalat. Secara ontologis, ilmu Ekonomi Islam membahas dua disiplin ilmu secara bersamaan. Dengan demikian, dalam operasionalnya ilmu Ekonomi Islam akan selalu bersumber dari kedua disiplin ilmu tersebut. Persoalan yang muncul kemudian adalah bagaimana memadukan antara pemikiran sekular ilmu ekonomi dengan pemikiran sakral yang terdapat dalam fiqh mu'amalat, mengingat bahwa sumber ilmu ekonomi adalah pemikiran manusia sedangkan sumber fiqh mu'amalat adalah wahyu yang didasarkan pada petunjuk Al-Qur'an dan Hadits Nabi. Dari sisi lain, teori kebenaran ilmu Ekonomi Islam dan ilmu fiqh mu'amalat tentu saja berbeda secara diametral. Tolok ukur kebenaran dalam ilmu ekonomi selalu mengacu kepada tiga teori kebenaran yang dipakai dalam filsafat ilmu yaitu teori koherensi (kesesuaian dengan teori yang sudah ada), teori korespondensi (kesesuaian dengan fenomena yang ada), dan teori pragmatisme (kesesuaian dengan kegunaannya). Sedangkan teori kebenaran fiqh mu'amalat mengacu secara ketat terhadap wahyu. Artinya, ekonomi akan dipandang benar bilamana tidak terdapat larangan dalam wahyu. Berdasarkan perbedaan sumber pengetahuan dan teori kebenaran yang digunakan, maka tentu saja sulit untuk memadukan antara ilmu ekonomi dengan fiqh mu'amalat. Lihat Daulay, Saleh Partaon, 2008, Posisi Ekonomi Islam di antara Ekonomi Konvensional dan Fiqh Mu'amalat: Kritik Epistemologis terhadap Ilmu Ekonomi Islam, Jakarta: MAARIF Institute. 
(wacana). Joan Scott (1988) secara lebih luas mendefinisikan wacana atau discourse sebagai sesuatu yang bukan hanya sebatas bahasa (language) atau teks semata, tetapi struktur spesifik dari pernyataanpernyataan, istilah-istilah, kategori-kategori dan kepercayaan-kepercayaan yang dikonstruksi secara historis, sosial dan institusional. Dengan mendeskripsikan wacana sebagai praktik sosial, ada implikasi-implikasi yang muncul, yakni dialektika hubungan antara kejadian diskursif tertentu dengan situasi serta institusi dan struktur sosial yang melingkupinya. Dalam konteks ini, kajian ini memperlihatkan bahwa istilah Ekonomi dan Iqtishad jelas dipengaruhi oleh struktur sosial dan diproduksi dalam interaksi sosial sebagaimana telah dijelaskan.

Kedua, berdasarkan hasil kajian, diketahui bahwa istilah ekonomi telah mengalami pergeseran filosofi, ideologi dan makna. Istilah ekonomi yang semula di dasarkan pada nilai-nilai agama, dipisahkan dari agama, sehingga ekonomi berideologi sekuler yang berakar pada filosofi materialisme, yang menempatkan manusia sebagai sebagai pusat dari segala hal kehidupan, dimana manusialah -bukan Tuhan- yang berhak menentukan kehidupannya sendiri. Makna ekonomi telah bergeser dari maknanya yang semula adalah pengelolaan aktivitas ekonomi, sosial, dan politik dengan kekeluargaan sebagai ruh (spirit) utamanya, bergeser menjadi pengelolaan ekonomi, sosial, dan politik dengan spirit utama individualisme. Filosofi,ideologi dan makna baru dari istilah ekonomi secara perlahan mengakar kuat dalam benak masyarakat sebagai wacana publik, dan menjadi sistem yang digunakan di seluruh dunia. Untuk dapat diterima sebagai wacana publik, filosofi, ideologi dan makna baru dari istilah ekonomi telah melalui proses panjang selama lebih dari 22 abad.

Ketiga, istilah Iqtishad tidak sama dengan ekonomi, dan Iqtishad tidak sama dengan Ekonomi Islam. Oleh karena itu, penggunaan istilah Ekonomi Islam sekarang ini menjadi tidak tepat dan tidak lagi relevan.

Keempat, konsep Iqtishad bersifat independen, tidak terkait dengan konsep ekonomi manapun. Dengan adanya penekanan terhadap hal ini, maka teori yang mengatakan bahwa Iqtishad adalah sama saja atau merupakan cabang atau bagian dari ekonomi tidak dapat dibenarkan.

Berdasarkan hasil kajian, penulis memberikan saran-saran sebagai berikut. Istilah Iqtishad yang memiliki filosofi, ideologi dan makna lebih sesuai dengan fitrah manusia dan lebih konprehensif perlu disosialisasikan secara intensif, terus-menerus, dan berkesinambungan kepada masyarakat dunia, baik muslim maupun non muslim hingga mampu menjadi wacana publik. Iqtishad diajarkan di kampus-kampus serta sekolah yang ada di seluruh dunia. Menjadikan Iqtishad sebagai budaya yang mengakar di masyarakat, menyiapkan mental mereka untuk melakukan interaksi dan asimilasi dengan konsep Iqtishad, dan kemudian menggerakkan mereka untuk menerapkan Iqtishad dalam kehidupan sehari-hari. Mendorong Negara-Negara muslim untuk menjadikan Iqtishad sebagai sistem resmi yang diakui negara.

Kajian terbatas seperti ini tentu menyisakan banyak celah untuk dilakukan penelitianlebih lanjut. Kajian ini hanya mengupas tentang Iqtishad sebagai sebuah istilah (terminologi), dansangat sedikit membahasIqtishadsebagai sebuah konsep dan sistem. Keterbatasan ini membuat penelitian ini belum dapat menggambarkan konsepIqtishad secara utuh. Karena itu penulis menyarankan untuk dilakukan penelitian lebih lanjut terhadap konsep dan sistem Iqtishad. Kepentingannya, agar Iqtishad dapat diketahui dan diterapkan dalam kehidupan manusia, menjadi konsep dan sistem yang mendunia, sehingga harapan akan lahirnya masyarakatyang hidup berdampingan secara damai, seimbang, sejahtera lahir dan bathin, sebagaimana pernah terjadi di masa kejayaan Islam selama belasan abad,dapat diwujudkan.

\section{DAFTAR RUJUKAN}

Al-Qur'an dan Terjemahannya. 2002. Departemen Agama Republik Indonesia.

Al-Misri, R. Y. 2005. Ushulul Iqtishad AlIslamiyah. Beirut. Dar al-Qalam.

Ash-Shadr, M.B. 1981. Iqtishaduna, Dirasah Maudhu'iyyah Tatanawalu bi an-Naqdi wa al-Bahtsi al-Madzahib al-Iqtishadiyah li al-Markisiyah wa al-Ra'samaliyah wa al-Islam fii Asasiha al-Fikriyah wa Tafashiiluha. Cetakan ke XIV. Beirut: Daarut Ta'aruf li al Mathbu'at.

Byarwati, A.2012. Penemuan Madzhab Ekonomi Islam: Studi Discourse Analysis Terhadap Pemikiran Muhammad Baqir Ash-Shadr Dalam Kitab Iqtishaduna, Disertasi Program Doktor Program Studi Ilmu Ekonomi Islam Universitas Airlangga Surabaya.

Chapra, M. U. 1999. Islam dan Tantangan Ekonomi. Surabaya. Risalah Gusti. 
Chapra, M. U. 2001. Masa Depan Ilmu Ekonomi, (terj.) Ikhwan Abidin, The Future of Economics: An Islamic Perspective. Jakarta. Gema Insani Press.

Daulay, S.P. 2008. Posisi Ekonomi Islam di antara Ekonomi Konvensional dan Fiqh Mu'amalat: Kritik Epistemologis terhadap Ilmu Ekonomi Islam. Jakarta. MAARIF Institute.

Deliarnov.2003. Perkembangan Pemikiran Ekonomi. Jakarta. RajaGrafindo Persada.

Dimyati. 2007. Teori Keuangan Islam,Rekonstruksi Metodologis Terhadap Konsep Keuangan al-Ghazali, Yogyakarta. UII Press.

Dimyati. 2001. Analisis Wacana, Pengantar Analisis Teks Media. Yogyakarta: LkiS

Fairclough, N. and R. Wodak. 1997. Critical Discourse Analysis. in Teun A. van Dijk (Ed.), Introduction to Discourse Analysis. London. Sage Publications.

Fairclough, N. 1989. Language and Power. London and New York: Longman Group UK.

Fairclough, N. 1995. Critical Discourse Analysis: The Critical Study of Language. London and New York: Longman Group Limited.

Faridi, F.R. (ed). 1991. Essay in Islamic Economic Analysis.Cetakan. 1, New Delhi. Genuine Publications \& Media PVT. LTD

Foucault, Michel. 1972. The Archeology of Knowledge \& The Discourse on Language. New York. Pantheon Books.

Fowler, R. 1985. Power, in Teun A. Van Dijk, T. (Ed.) Handbook of Discourse Analysis Volume 4: Discourse Analysis in Society. London. Academic Press.

Gee, J.P. 1999. An Introducyion to Discourse Analysis, Theory and Method. New York. Routledge.

Hasanuzzaman, S.M. 1991. Economic Functions of an Islamic States; the Early Experience. Karachi. The Islamic Foundation

Iedema, R. and R. Wodak. 1999. Introduction: Organizational Discourses and
Politics", in Discourse \& Society. An International Journal for the Study of Discourse and Communication in The Social, Political and Cultural Contexts. Volume 10, Number 1,hal. 5-19.

Mannan, M. A. 1984. Frontiers of Islamic Economic. Delhi. Idarah Adabiyati.

Mannan, M. A. 1984. Islamic Economics: Theory and Practice.. Delhi. Sh. M. Ashraf

Perwataatmadja, K. A dan A. Byarwati. 2008. Jejak Rekam Ekonomi Islam: Refleksi Peristiwa Ekonomi Dan Pemikiran Para Ahli Sepanjang Sejarah Kekhalifahan. Jakarta. Cicero Publishing.

Polli, W.I.M, Tonggak-Tonggak Sejarah Pemikiran Ekonomi, 2010, Surabaya: Brilian Internasional.

Rahardjo, M. D. 1999. Islam dan Transformasi Sosial-Ekonomi. Jakarta: LSAF.

Rahardjo, M. D. 1999, Wacana Ekonomi Islam Kontemporer, Surabaya: Risalah Gusti.

Roy, O. 1996, The Failure, alih bahasa Carol Volk, cet. 2, Harvard University Press

Samuelson, P. dan W. D. Nordhaus. 2001. Microeconomic. Edisi 17. New York. McGraw-Hill.

Schacht, J. 1974. The Legacy of Islam. Oxford. Clarendon Press

Swasono, S.E.1997. Pasar-Bebas yang Imajiner: Distorsi Politik dan Pertentangan Kepentingan Internasional. Mimeo. Kantor Menko Ekuin.

Swasono, S.E.2008. Ekspose Ekonomika, Mewaspadai Globalisme dan Pasar Bebas. Yogyakarta. Pusat Studi Ekonomi Pancasila Universitas Gajah Mada.

Van Dijk, T. A. 2003. Ideology and Discourse: A Multidisciplinary Introduction. Internet Course for the Oberta de Catalunya (UOC).

Van Dijk, T. A. 1999."Critical Discourse Analysis and Conversation Analysis, in Discourse \& Society". An International Journal for the Study of Discourse and Communication in The Social, Political and Cultural Contexts. Volume 10, Number 4, p. 459-460. 